History), 1963). In general format and contents this is similar to the previous edition of 1962 , and the difference is mainly due to four additional pages of text and two extra illustrations. This is chiefly an account of the recently opened botanical gallery and illustrations of their dioramas and wall cases. It is unfortunate that one illustration scarcely does credit to the attractive mineral barytes.

\section{The Durban Museum and Art Gallery}

The report for 1961-62 of the Durban Museum and Art Gallery records the completion of the new Hall of Marine Life and the start of five new displays in the entrance hall (Pp. 24. Durban: Durban Museum and Art Gallery, 1963). An illustrated guide to the three major modernized galleries has been issued and several collecting expeditions have been made by the staff. The list of papers published is an impressive one considering the size of the staff.

\section{Department of Scientific and Industrial Research Grants,} 1963

D.S.I.R. Research Grants, 1963, summarizes information regarding the Grants for Special Researches awarded by the Department of Scientific and Industrial Research (Pp. vi + 9. London: H.M.S.O., 1963. 1s. 6d. net). These grants are given to supplement resources derived from the University Grants Committee or elsewhere and are not intended to meet the entire cost of research projects or to replace existing resources. The awards are for investigators who are already of acknowledged standing in their subjects. Grants may be given for the support of researches in astronomy, biology, chemistry, geology, mathematics, physics and the sciences between and adjoining these, and also in applied science and technology, and engineering; but applications for assistance in subjects in which the Agrieultural Research Council, the Development Commission, the Medical Research Council or the Nature Conservaney are directly interested should be made to the appropriate body. Applications for grants in certain branches of the humanities and social sciences may also be considered where appropriate. Notes on Nato research grants and on senior visiting fellowships of the Organization for Economic Co-operation and Development are included.

\section{Gordon Research Conferences, 1963}

THE Gordon Research Conferences, the purpose of which is to stimulate research in universities, research foundations and industrial laboratories by fostering the exchange of ideas and information, are to be held this year in four research sehools in New Hampshire during the period June 10-August 30. Forty-eight informal conferences, each lasting five days, will be held, their subjects covering a wide range of topics in the physical and biological sciences. Residence and registration charges for each conference amount to 100 dollars. Applications should be addressed to, and further informa. tion can be obtained from, W. George Parks, director, Gordon Research Conference, University of Rhode Island, Kingston, Rhode Island.

\section{"Notions of Niche and Competition Among Animals, with Special Reference to Freshwater Fish"}

Dr. A. H. Weatherley, of the Department of Zoology, School of General Studies, Australian National University, Canberra, has written to the Editor stating that in his article under the above title, appearing on p. 14 of the January 5 issue of Nature, he erroneously attributed a definition of competition among animals by Dr. Alec Milne, Agricultural Research Council Unit of Insect Physiology, to Prof. J. L. Harper, University College of North Wales. Dr. Weatherley wishes to apologize for this error to both Prof. Harper and Dr. Milne.
University News :

Bristol

THe following appointments to lectureships have been announced: B. M. Bird (electrical engineering); Dr. A. Keller (physics); Dr. R. H. Ottewill (physical chemistry within the Department of Physical and Inorganic Chemistry).

London

THE following titles have been conferred: professor of the archæology of the Roman Provinces, on Mr. S. S. Frere, in respect of his post at the Institute of Archæology; professor of hæmatology on Dr. P. L. Mollison, in respect of his post at St. Mary's Hospital Medical School; reader in pharmacology, on Dr. J. R. Hodges, in respect of his post at the Royal Free Hospital School of Medicine; reader in biophysics, on Dr. R. Miledi, in respect of his post at University College; reader in physiology, on Dr. Patricia P. Scott, in respect of her post at the Royal Free Hospital School of Medicine; reader in human nutrition, on Dr. G. R. Wadsworth, in respect of his post at Queen Flizabeth College.

Prof. M. G. Marwick has been appointed to the foundation chair of anthropology and sociology in the University. Prof. Marwick is at present professor of social anthropology and head of the Department of Social Anthropology and African Administration in the University of the Witwatersrand. During 1962 he was Simon Senior Research Fellow in the University of Manchester.

\section{Announcements}

From January 1963, the Council of Scientific and Industrial Research, New Delhi, is issuing research communications in a series of four periodicals: Indian Journal of Pure and Applied Physics; Indian Journal of Chemistry; Indian Journal of Technology; and the Indian Journal of Experimental Biology. The Journal of Scientific and Industrial Research will continue with all the features included up to December 1962 in its Section $A$.

The Low Temperature Research Station, Cambridge, will hold open days during May 22-23, at which recent and current work will be displayed. Further information can be obtained from the Director, Low Temperature Research Station, Downing Street, Cambridge.

A Symposium on "Moulds for Reinforced Plastics", arranged by the Plastics Institute Reinforced Plastics Group, will be held in London on May 28. Further information can be obtained from J. N. Ratcliffe, Plastics Institute, 6 Mandeville Place, London, W.I.

THe annual conference of the Ergonomics Research Society will be held at the College of Aeronautics, Cranfield, during April 1-4. Subjects under discussion will include: process control; workplace layout; machine tools; engineering production; the comprehension of engineering drawings; the effects of heat; the teaching of ergonomies; the future of ergonomics; criteria in ergonomics; the elderly worker in industry. Further information can be obtained from Mr. David Whitfield, Ergonomies Laboratory, College of Aeronautics, Cranfield, Bletchley, Bucks.

A symposium on "The Colorimetry of Near Whites", organized by the Colour Group (Great Britain), will bo held at the Imperial College of Science and Technology on April 3. The programme will include: the measurement of whiteness; the scan-test roference instrumont for reflectometry; the colorimetry of fluorescent whites; light sourcos for matching near whites. There will also be an exhibition of colorimeters, spoctrophotometers, light sources, colour atlases, colour filters, colour vision tests and allied equipment. The group's first Newton Lecture entitled "The Rays are not Coloured" will be delivered by Prof. W. D. Wright. Further information can be obtained from F. J. B. Wall, Physies Research Laboratory, Ilford Ltd., Woodman Road, Brentwood, Essex. 